Duško Čikara

\title{
From a Hypothesis on the Development of the Layout of Poklek Manor in Zagorska Sela, towards a hitherto Unknown Type of Residential Architecture in Continental Croatia
}

Keywords: single-room layout, manor house, fortalitium, Continental Croatia, Middle Ages, refuge, Renaissance

DOI: $10.4312 /$ ars.11.1.171-188

\section{Introduction}

The basic disposition of country mansions in northwestern Croatia, that part of the territory that was spared Ottoman raids, demonstrates two clearly different categories: mansions featuring arcaded courtyards, and more modest, compact and contained single-wing curioe. The prevailing expert opinion, based mainly on the shape of vaulting, seems to be that the curioe featuring porches are the earliest parts of larger mansions consisting of several wings. Based on the results of conservation research and field inspection ${ }^{1}$, this paper explores the probability that the indicated mansions were not erected ex nihilo, but that they incorporated earlier single-room structures, thus demonstrating a hitherto unknown pattern of layout consisting of a roughly square room and a narrow corridor. The research results further indicate that the habitual name curia in Continental Croatia has been used exactly for those presumed structures since the $15^{\text {th }}$ century.

To further validate the assumption of typologically identically organized nuclei within more complex structures, as well as go beyond random guesswork, a systematic inquiry of all published layouts of curioe and mansions, mainly in Transmontane Croatia/Hrvatsko Zagorje (Reberski, 2008), has been carried out. The aforementioned pattern was identified in many such buildings, and this called for a field inspection of several sites whose ruinous conditions, making earlier layers visible, allowed for an examination without probing the parts that belong to the presumed single-room

1 Upon invitation by Prof. Lj. Miščević (Faculty of Architecture in Zagreb) in the fall of 2011 the author, together with Senior Curator architect A. Curić, investigated façades of the Poklek curia. By the end of 2015, together with restorers I. Drmić and R. Mavar, and Senior Curator architect A. Škevin Mikulandra, exploration of the Count Drašković mansion façades in Veliki Bukovec was initiated. 
structures. In order to objectively approach the problem, we took into account the published results of several earlier and independently conducted studies that more or less confirmed the hypothesis, but, being unrelated to each other, have remained on the level of a particular insight, rather than enabling a broad generalization. ${ }^{2}$ Several historic layouts of similar spatial organization can also be found in the research literature.

This methodological approach was the only one possible, since, under existing circumstances, the hypothesis could not be confirmed within a reasonable timeframe with the use of a well-targeted and systematic study of a sufficiently large sample. Therefore, the conclusions set out in this paper must necessarily be perceived as an initial set of guidelines for future conservation-restoration and archaeological research, to be taken into account in confirmation of the above hypothesis, and aimed at expanding and systematizing knowledge of the typology and genesis of the residential architecture in a possibly much larger geographical area.

\section{The identification of the presumed initial spatial nucleus of the Poklek Manor House}

The two-storey Poklek Manor House stands on a plain above the Sutla valley close to Zagorska Sela. It supposedly originated from the early $18^{\text {th }}$ century (Reberski, 2008, 674676), although the estate of the same name was in the hands of the noble Rattkay family (Gulin, 1995, 58) as early as 1571. A narrow corridor extends through the entire manor, featuring groin vaults on the ground-floor and Bohemian vaults on the first. On each side of the corridor there are a couple of rooms with barrel vaults on the ground-floor and flat ceilings on the first floor. A basement is situated below the southwestern part. Since the interior was not explored, attention has been directed to the variously shaped openings on the asymmetrical façades made of rubble. Probes to obtain more precise data have been carried out around the openings whenever possible. According to the manner of distributing the load and material used for jambs, they may be linked to three different parts of the manor, i.e. to specific rooms. Therefore, rubble stone relieving arches are visible above all the windows on both the ground and first floor of the southwest part. The simple frames of the two first floor openings on the west side of the southern façade protrude from the façade level (Fig. 1 upper right), and no traces of a later insertion are visible. It is thus a logical supposition that the plaster jambs of the two southern apertures on the western façade imitate the abovementioned stone jambs (Fig. 1 upper left). ${ }^{3}$ The eastern part of the southern façade is set back from the building line of the western part,

2 Unfortunately, some individual investigations involving crucial evidence have not been carried out lege artis.

3 Since the western façade is exposed to strong weather, the original stone jambs were probably obliterated and later replaced in plaster. 
and single asymmetrically positioned windows show no visible relieving arches. Their height is different from those on the western part, and the irregular stone jambs are obviously spolia. The apertures on the part of the transversal protrusion closer to the basic volume are executed in the same manner (Fig. 1 lower left). They are also shaped in thin plaster slightly protruding from the façade. The same is true of the openings in the two southern axes of the eastern façade (Fig. 1 lower right). On the other hand, the apertures in the northern part have prominent stone frames, whilst their relieving arches are mostly made of bricks. The remains of a hammered-out one quarter moulding are visible on the outer side of the window ledges on the first floor of the northern façade, as well as on the northern parts of western and eastern façades (Fig. 1 upper left, Fig. 2 left), is due to the later installation of the $19^{\text {th }}$ century wooden window frames (Fig. 2 centre). Identically profiled blocks have been used to cover the parapets of the portico on the first floor of a later addition of the transversal protrusion (Fig. 2 right).
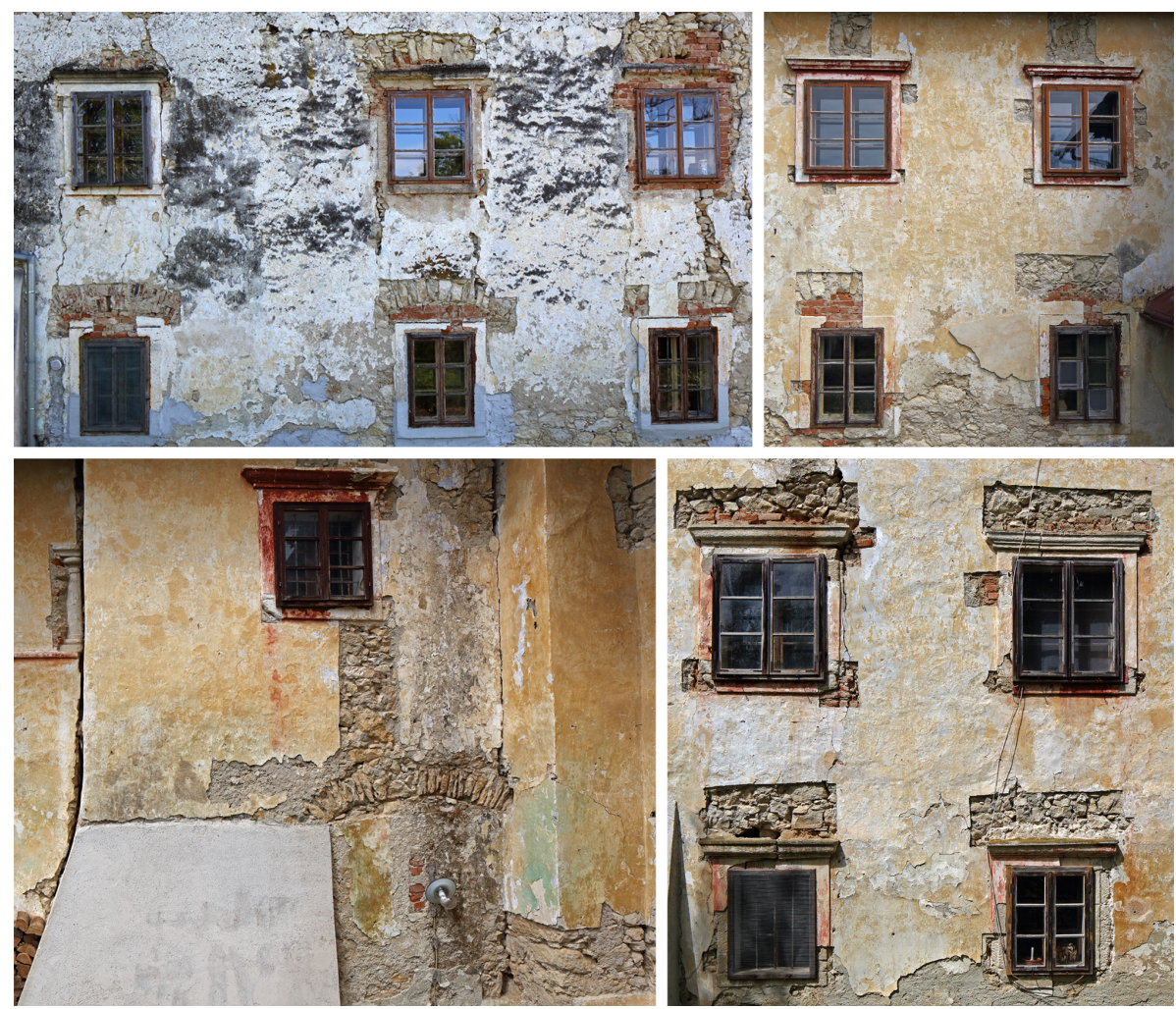

Fig. 1: Zagorska Sela, Poklek Manor, window axes of western façade (above left); western section of southern façade (above right); portion of transversal protrusion and eastern section of southern façade (below left; southern portion of eastern façade (below right), photo: J. Rasol, 2016. 

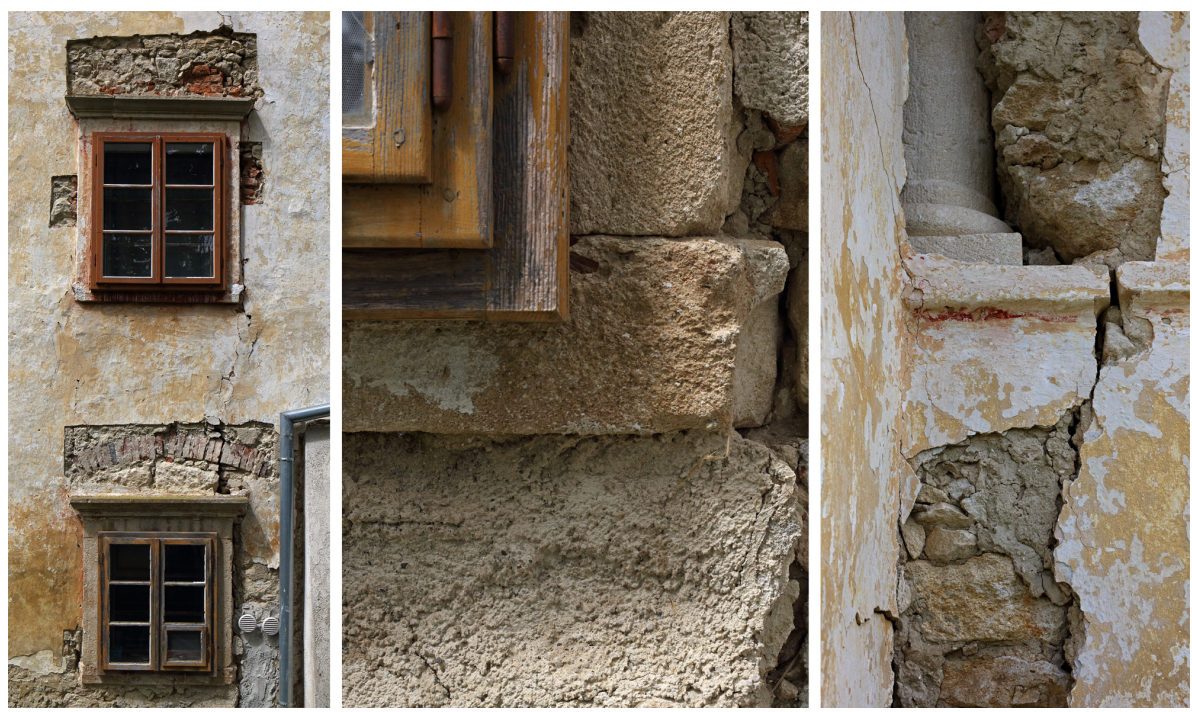

Fig. 2: Zagorska Sela, Poklek Manor, northern window axis of eastern façade (left); detail of stone carving at the northern window axis of eastern façade (centre); stone carving on the western façade of the transversal protrusion (right), photo: J. Rasol, 2016.

The heterogeneous architectural decoration of the façade openings, where certain forms and their construction are characteristic of specific parts/rooms of the building, and the diminished thickness of the northern part of the perimeter and the unevenness of the building line on the southern façade, lead us to the conclusion that over time even this modest structure increased in size. Otherwise, such an unusual construction could only indicate a peculiar, quite individual, approach to designing this part, an idea that must be ruled out. Furthermore, abutments on three corners - southwest excluded, plus a basement which is only under one part of the building, leads to us to conclude that the original compact dwelling consisted of a single $7 \times 6 \mathrm{~m}$ room with an adjoining entrance corridor in both the basement and the ground-floor, and a narrow hall on the first floor stretching along its entire depth (Fig. 3 a). The vaults in the corridor also correspond to the plan of the presumed original core. Judging by the ground-floor vaults, the original upward staircase might have been within the eastern wall where the perimeter wall is at its thickest. ${ }^{4}$ The entrance to the basement was originally protected by a portico whose arches were walled up by the construction a later staircase.

4 Judging from the $120 \mathrm{~cm}$ thick wall within which a staircase to the attic has been built. 


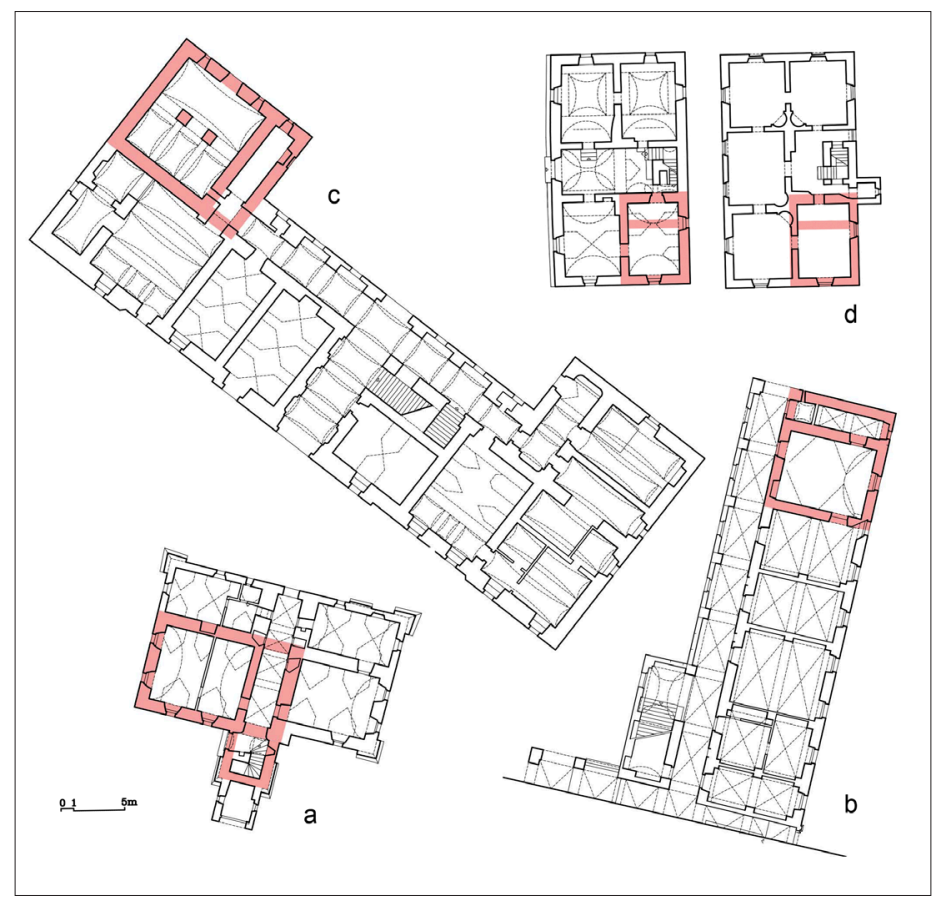

Fig. 3: (a) Zagorska sela, Poklek Manor, ground-floor plan, drawing by M. Stepinac/ IPU, 2001.; print: R. Mavar, 2016; (b) Veliki Bukovec Mansion, ground-floor plan, drawing: M. Stepinac/IPU, 1995/6.; print: R. Mavar, 2016; (c) Poznanovec Mansion, ground-floor plan, drawing: M. Stepinac/IPU, 2001.; print: R. Mavar, 2016; (d) Borkovec Manor, ground-floor plan (left), drawing: M. Stepinac/IPU, 2001.; print: R. Mavar, 2016; and the upper-floor plan (right), drawing: Ž. Burić after M. Bošnjak; print: R. Mavar, 2016.

\section{Graf Drašković Mansion in Veliki Bukovec featuring a single-room core}

Elements of the single-room spatial organization have been recognized in the course of research into Count Josip Kazimir Draškovićs late Baroque mansion in Veliki Bukovec. The manor is situated in the Podravina plain between the rivers of Bednja and Plitvica. The manor house itself is believed to have been erected after Count Ivan III took over the estate in 1643, while a fortalitium existed earlier at this site (Horvat-Levaj and Reberski, 1997, 339). In contrast to the groin vaults with transverse arches in the remaining part of the ground-floor, the room at the northern end $(6,5 \times 5,5 \mathrm{~m})$ features barrel vaults with lateral inserts. ${ }^{5}$ An apparently illogically placed narrow room is situated

5 Their asymmetry of the plan may be explained by the need to achieve a functional rectangular surface on the west wall with no openings at the point of contact of longitudinal partially executed inserts. 
at the very end of a complex structure (Fig. 3 b). Contrary to the Poklek Manor, where parts have obviously been constructed separately, when reconstructing the frontispiece in the late Baroque, the third ground-floor window looking from the north cuts into the partition wall that represents the southeast corner of a rectangular room, i.e. the southeast corner of the presumed earlier building, possibly the aforementioned manor (Horvat-Levaj and Reberski, 1997, 341). ${ }^{6}$ The assumption that the elongated narrow room was an entrance to the earlier building is further enhanced by the groove in the brick wall leading towards the ground left of the entrance situated in the position of the farthest window of the original mansion design. An additional row of bricks under the original lintel (Fig. 4 right) confirms existence of an opening before the window was added. The vault of the rectangular room has been cut into in order to put up lintels of possibly larger window niches in the eastern wall (Fig. 4, left). Bearing in mind the insufficient thickness of the walls for a construction of the built-in staircase, the upper floor of the presumed core must have been reached from the corridor through a staircase presumably situated on its west side, where, instead of a groin vault, there is a Bohemian dome. The lesser thickness of the presumed southern perimeter wall on the upper floor of the possible core may indicate that an unnecessarily thicker wall was demolished, although the entire upper floor might also have been constructed of wood. ${ }^{7}$

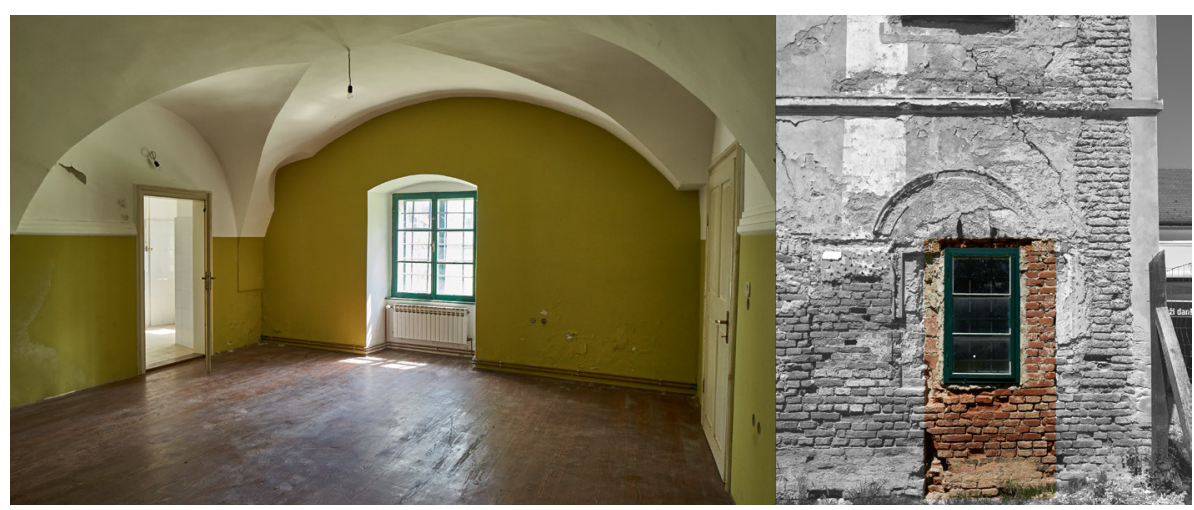

Fig. 4: Veliki Bukovec, Drašković Mansion, cut in vault next to the eastern wall of the rectangular room of the presumed original core (left); built-in entrance to the presumed original core (right), photo: J. Rasol, 2016.; print R. Mavar.

6 In the original layout of the mansion the rectangular room had two axes on the eastern front (noted by the author). A square niche plastered on three sides was discovered later in the western portion of the southern wall in that room. It was eliminated in the course of building a fireplace, above the level of the parapet of the late Baroque windows. The original floor level was $25 \mathrm{~cm}$ beneath the current floor.

7 Since the axes of former openings revealed on the ground-floor of the Vidovec mansion are not continued on the upper floor of the historically shaped northern façade, this points to the upper floor having been possibly built in wood. Differing sizes and design of openings suggest that additions were made to the castle's northern wing, i.e., pointing to the presence of the characteristic core. 


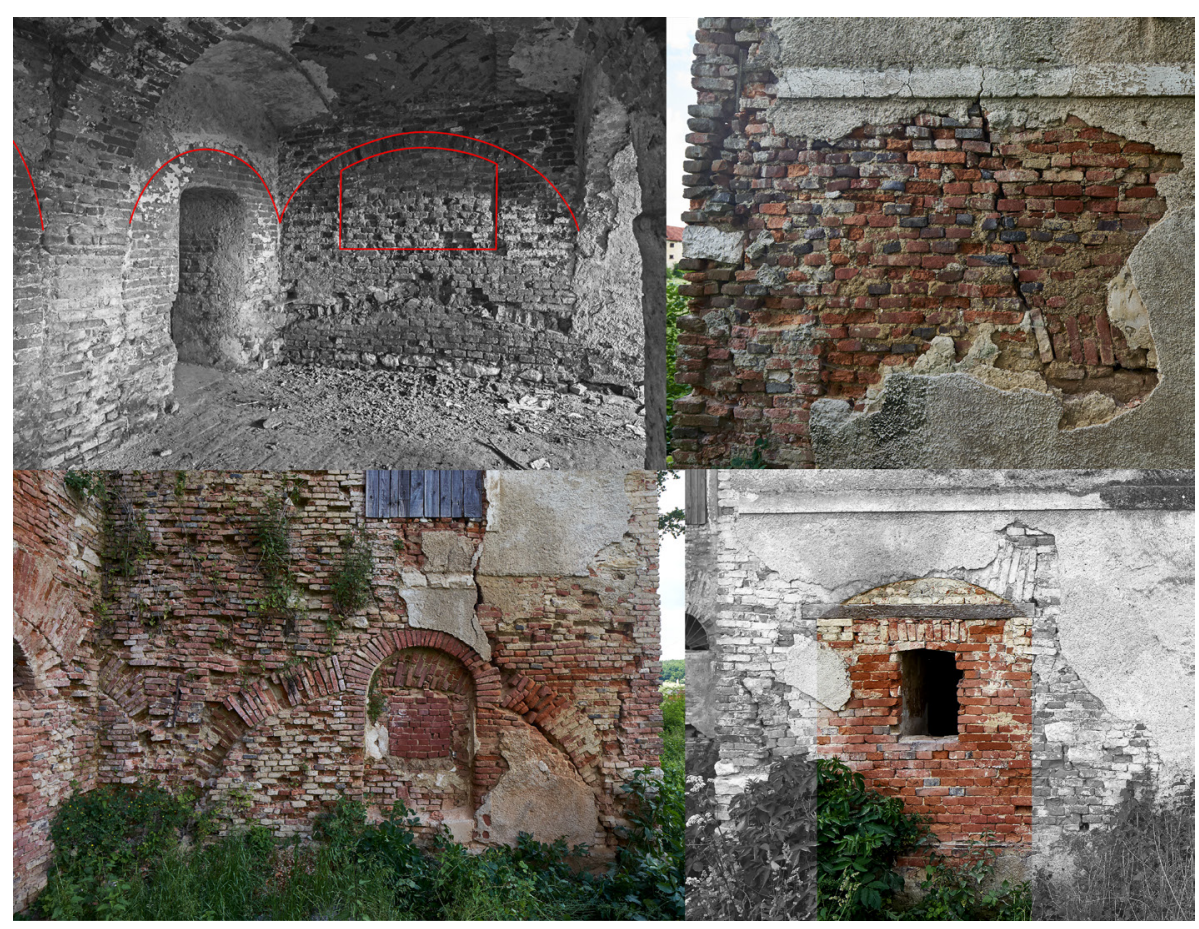

Fig. 5: Poznanovec, Sermage Mansion, southwestern portion of the rectangular ground-floor room believed to be a part of the original core (above left); built-in window and traces of an earlier plaster layer in the ground-floor of the northern part of the western façade (above right); ground-floor of eastern façade of western projection (below left); part of southern façade of western projection (below right), photo: J. Rasol, 2016.; print: R. Mavar, 2016.

\section{Possible single-room core of the Poznanovec mansion and the Borkovec manor - from observations on the plan to results of field inspection}

Within a complex asymmetrical plan of the late Baroque mansion of Poznanovec, situated near the point where the Velika flows into the Krapina and belonging to the Sermage family, a distinctive pattern of spatial organization consisting of a massive western corpus has been recognized (Fig. 3 c). Although the larger room piers bear Bohemian vaults with transverse arches, the structure's layers are visible due to poor repairs that were made to the building. Therefore, traces of deeper, probably groin, vaults, corresponding to walled-up window niches on the west wall of the square room, indicate their logical connection (Fig. 5 above left). Under the present-day plaster, the remains of smooth white-painted roughed up plaster, which 
used to adorn all the façades of the building, were found above the lintel of the aforementioned walled-up ground-floor opening (this may be the same as the older and damaged layer of plaster on the walled-up sections) on the western projection (Fig. 5 above right). ${ }^{8}$ Furthermore, a relieving system is visible on the eastern front of the projection on the ground-floor, with a wide and a relatively narrow semicircular relieving arch (Fig. 5 lower left). The latter is partly covered due to the erection of the castle's principal wing, and part of it on the ground-floor is visible from inside. ${ }^{9}$ The narrow corridor features a shallow Bohemian vault. Judging from the remains of the removed wall structure, it seems that the wider relieving arch, which is visible on the façade, used to bear a barrel vault with transverse arches. A segment lintel covering a significantly larger span is visible above the opening that provides daylight to the corridor on the northern façade. This might represent remains of a demolished entrance on its narrower side, arguing for the existence of the characteristic core (Fig. 5 lower right). The manor on this estate was mentioned as early as 1581 (Reberski, 2008, 107).

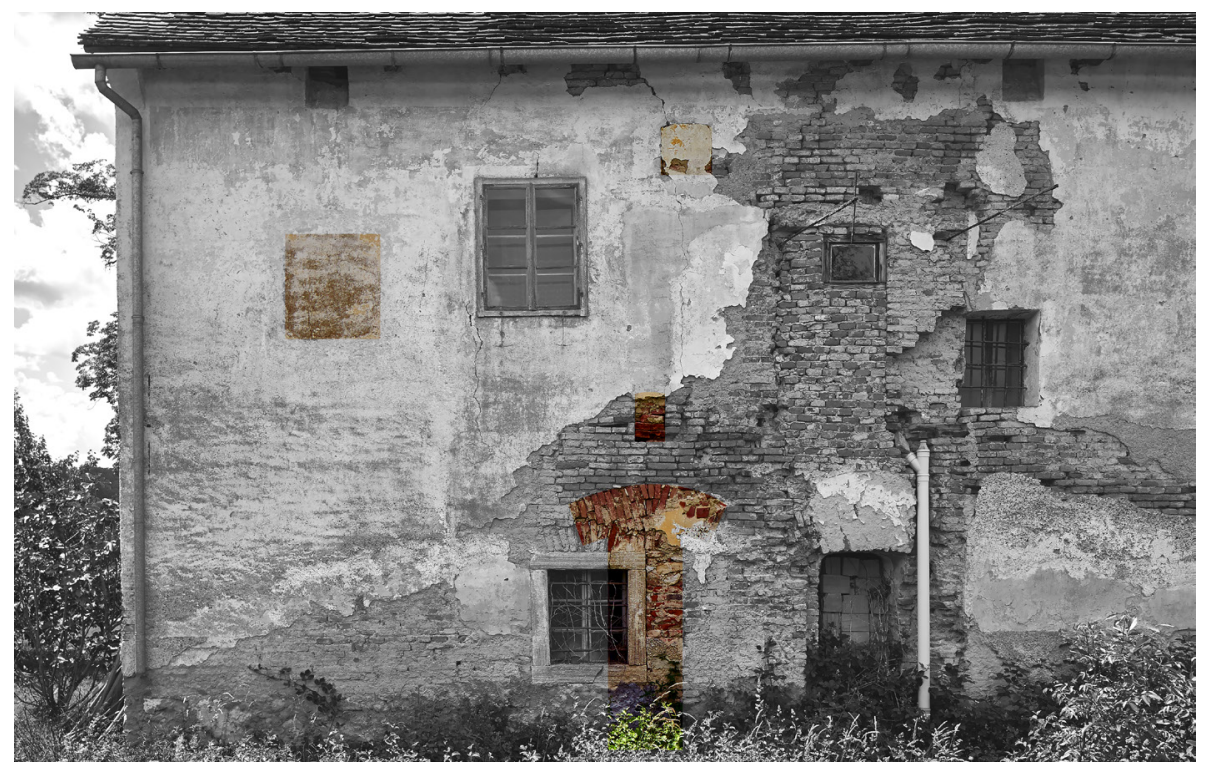

Fig. 6: Borkovec, southern part of eastern façade, photo: J. Rasol, 2016; print: R. Mavar.

The small size of the presumed cores becomes obvious when looking at the structure at the southeastern part of the Borkovec manor, which is situated on the gentle slope along the Zlatarščica vale north of Zlatar. According to the inscription

8 It will be up to lab tests to establish if this discovery may be analogous to the remains of plaster applied before the execution of the eastern terrace.

9 The southern end was demolished when passageways were established on the ground-floor. 
above the entrance, this structure was built before 1779, and a manor in Borkovec was also mentioned several years earlier (Reberski, 2008, 729). Two ground-floor rooms in the southern part of the house can be considered the earliest part, since identical stone lintels are used here. However, walled-in openings are visible on the dilapidated eastern façade (Fig. 6); the massive lintel above the walled-in narrower opening on the ground-floor, probably the remains of an entrance into the farthest northern part of the presumed core, as well as walled-in smaller openings on approximately the same axis ${ }^{10}$, plus the walled-in window centrally positioned towards a presumed smaller rectangular room, all indicate that the smaller curia was not built in one step. The size of the ground-floor rooms does not match those of the first floor, except for the room at the southeastern end (Marković, 1975, 66).${ }^{11}$ As this is the only part of the curia that has retained its original layout, everything points to its being the original core (Fig. 3 d). ${ }^{12}$

\section{Single-room layout of the clergy's curiæ on Kaptol in Zagreb}

After examining the $16^{\text {th }}$ century Propositus curia at Kaptol 7, and based on the extent of the earliest façade plaster and on discovering a walled-in Late Gothic window on the southern (now demolished) wall of a square room above the one with a brick column bearing groin vaults (Fig. 7), ${ }^{13}$ the architect and conservationist Davor Stepinac confirmed the existence of a single-room spatial core within this structure. As opposed to the later sections, there is no basement there. Plans of the canonical curia at Kaptol $20,{ }^{14}$ as well as others, indicate that buildings with our characteristic layout could be found in several urban and proto-urban centres of north-western Croatia.

10 Judging by their level, it might be assumed that they were on the same level as the floors in the corridor, which indicates a possible defensive function.

11 In the spirit of the time the owners wished to accentuate the central part. However, this idea was carried out only on the first floor, while the lateral parts are more ample on the ground-floor. This does not mean that the builder was inept. Bearing in mind the obvious growth of the building one must assume that room size defined by the earlier southern part was too large for the financial capacities of the owners, which resulted in the unrelated layout of the upper floor.

12 The ground plan size is not unlike that of the Židovski stolp in Maribor.

13 Investigations were carried out by the City Office of Monuments Protection, but to this author's request the Office replied that they had no such documentation in their possession.

14 The single-room core is clearly visible, as demonstrated by smaller basement (Križić Roban, 1997, 114). 


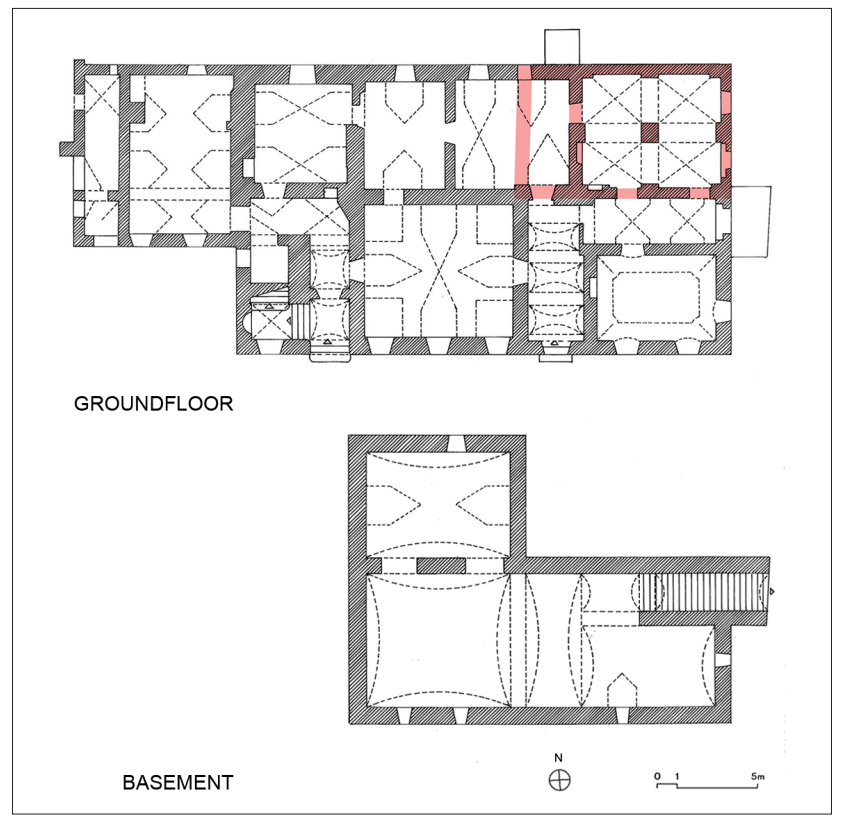

Fig. 7: Zagreb, ground-floor and basement plan of Kaptol 7, drawings: I. Haničar Buljan/IPU, 1996.; print: R, Mavar, 2016.

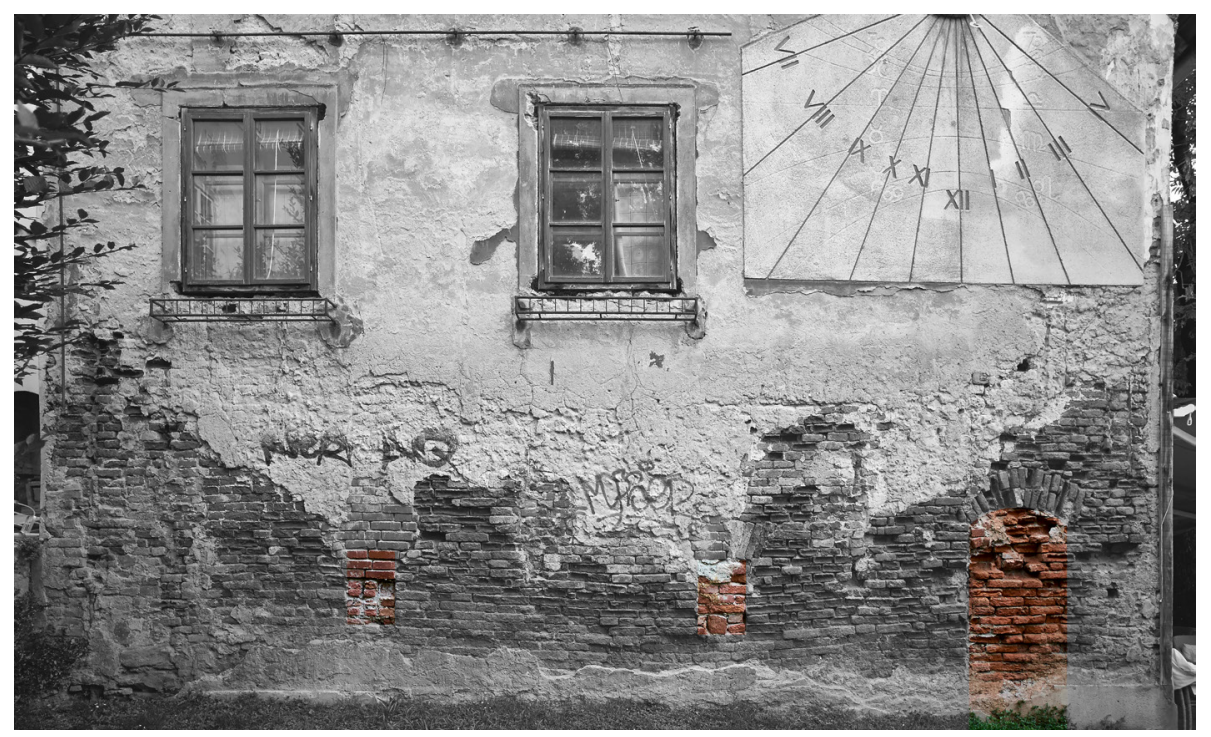

Fig. 8: Zagreb, southern façade of 25 Tkalčićeva st., photo: J. Rasol, 2016, print: R. Mavar. 


\section{Two characteristic façades from Zagreb suburbia}

The worn out southern front of the house in Tkalčićeva 25 (Fig. 8), certainly dating from the $18^{\text {th }}$ century (Lisac, 1997, 227), features a characteristic layout with the entrance at one end and two window axes. Its small entrance does not indicate an earlier open portico, and the length of a possible closed corridor along the now covered bed of the Medveščak stream can only be estimated, since the house has seen at least one alteration. The presumed square room was situated in the western part of the house, facing, like all other houses on the west side of Tkalčićeva street, towards Kožarska street. The window apertures in this room are extremely small and inappropriate for a dwelling, thus indicating that the building must have had another floor. The almost identical disposition of the northern part of the west façade of the house at Vlaška street 5 abutting the southern section of the Kaptol ramparts also indicates, as well as the basement, an expansion of the ground plan.

\section{Sutinsko - two closely set historically recorded curiæ with a characteristic single-room layout; their respective identification in the context of archaeological excavations}

A surprising possibility of two countryside dwellings sited close to each other arises from documents stating that two curice coexisted in Sutinsko on the estate of local gentry north of Mače, one mentioned in 1558 in the immediate vicinity of a second curia that seems to have some defensive elements (Laszowski, 1943, 12). They appear to have been left to deteriorate, perhaps due to unresolved property issues, and were already marked as ruins in 1651 (Laszowski, 1943, 14). In 1910, the foundations of unspecified buildings were discovered on the meadows of the Sutinsko estate next to the Sutinski creek. Thanks to a sketch, we know of the single-room layout of one of these (Fig. 9 left). New archaeological excavations might detect the foundations of a second curia, and confirm the hypothesis that the sketch applies to one of them. ${ }^{15}$ The width of the presumed corridor is barely a half meter at the footing level. However, when compared to the clear span of the Gothic entrance at the end of the eastern façade of Kaptol 26 curia, measuring only $52 \mathrm{~cm}$ (Fig. 9 right), such a small size is not surprising. ${ }^{16}$

15 The obvious inclusion of two separate single-room cores within the body of the two-storey Šcrbinec curia south of Belec (visible joints of the perimeter, irregular outline of the building's central section and a later opening of the original corridor of the southern core) adds additional points to this. The destiny of the Sutinsko curice bypassed the two presumed cores of the Mirkovec castle. Slightly larger window openings on the central part of older wing also point to a possible, in this case more complex, inclusion. In the smaller presumed core that, due to its size, might have originally been a fortalitium, the entrance corridor seems to taper, apparently towards the presumed entrance, to discourage possible invaders. Since the newer wing of the castle slightly bends, more than two cores might have been included in Mirkovec.

16 This is due to the smaller stature of the people, on the one hand, and on the other a desire to discourage invaders. 


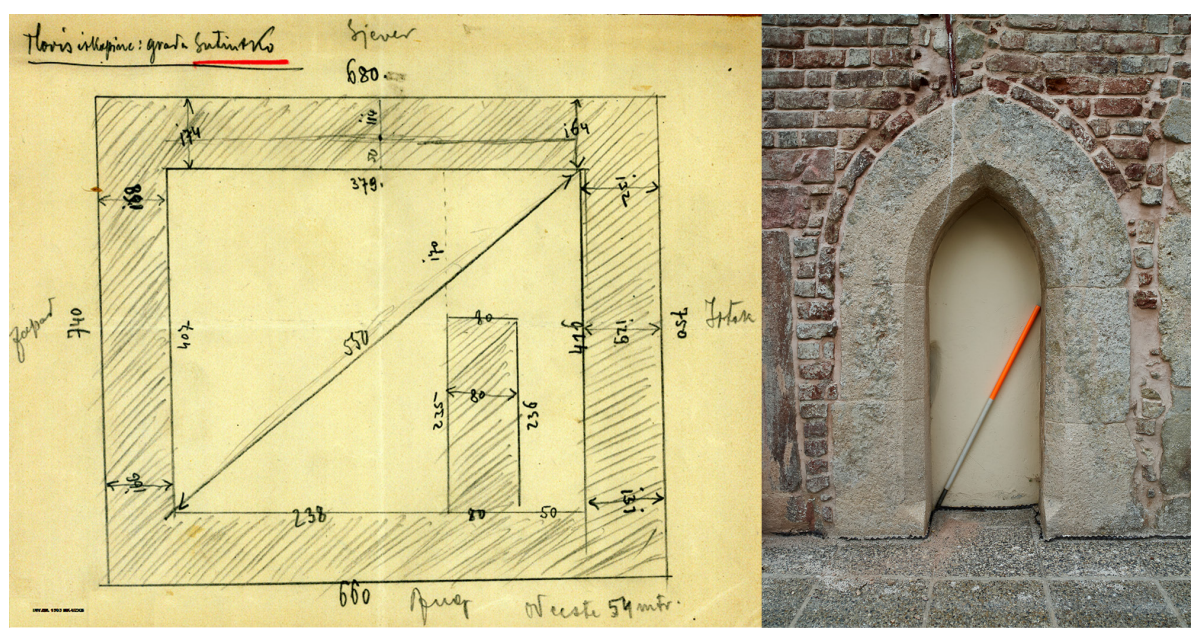

Fig. 9: Sutinsko excavation and Zagreb, Kaptol 26 original entrance. Left: MK-UZBK, inv. no. 1503; right photo J. Rasol 2016.

\section{Prozor fortification near Otočac - possible spread of characteristic single-room buildings elsewhere in Continental Croatia}

The fact that until the $16^{\text {th }}$ century the entire Continental Croatia and Slavonia represented a single cultural space leads to the assumption that the single-room layout pattern might appear in both the south and the east. ${ }^{17}$ It is well known that the Gacka, Krbava and Lika areas were densely covered with feudal seats during the Middle Ages. However, due to centuries of devastation it would be difficult to answer the question as to whether there were any single-room structures here. A solitary example is the plan of Prozor military frontier fortification, previously held by the Frankopan princes, which possibly served as a refugium and whose exact position has not yet been established. A modest building abutting the perimeter in one of the corners of the fortification is marked as the commander's dwelling (Fig. 10). As the commander was a high-ranking person, the layout seems to reflect the feudal building tradition was also applied in the southern areas. ${ }^{18}$

17 Studying their expansion towards both the coastal area and Bosnia might provide some interesting information. A good example might be part of the Khuen-Belassy castle in Nuštar, which was probably erected on earlier foundations, and its masonry may originate from before the Ottoman invasions. (Research has been carried out by the Institute of Art History, R. Vučetić and I. Haničar Buljan).

18 The ground-floor of the Frankopan castle at Novigrad-on-Dobra ( $16^{\text {th }}$ century) also features the characteristic ground-plan pattern abutting the southeastern tower; it could be the original core of a more complex dwelling. 


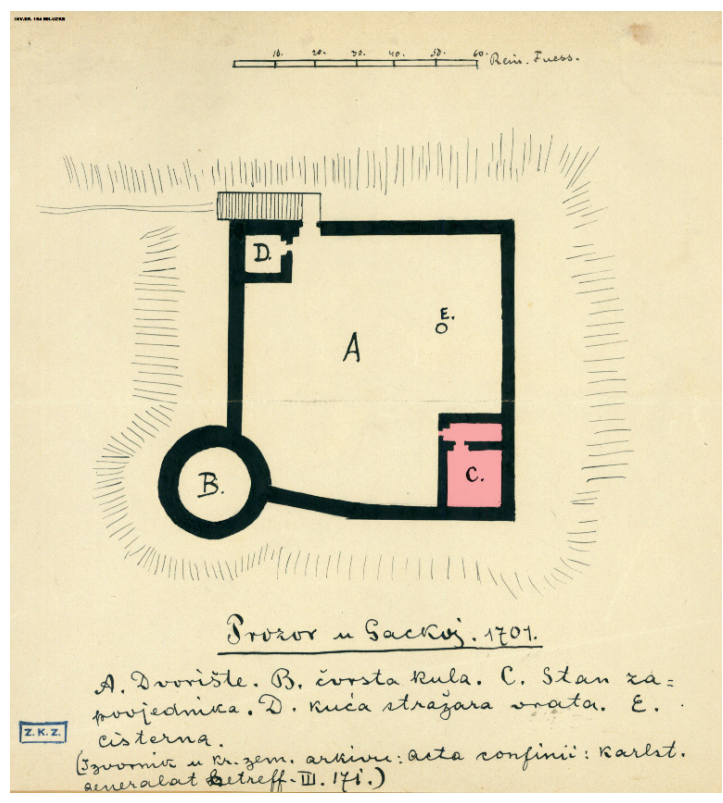

Fig. 10: Prozor, ground-floor plan of the fort, drawing: Gj. Szabo after G. Pieroni, before 1920; MK-UZBK inv. no. 164; print: R. Mavar, 2016.

\section{Conclusion: single-room curiæ as the simplest layout of feudal dwellings in mainland Croatia}

The existence of a single-room layout pattern in Continental Croatia seems to be confirmed by several partially completed conservation investigations, as well as by conclusions obtained from direct examinations into the structures of several complex buildings. Historical drawings that clearly depict such buildings that were not incorporated into more complex structures also lend more credence to this idea. A square room usually featuring two window axes, each on two fronts, plus a lateral corridor along the entire square room, indicates a possible core within a more complex layout. ${ }^{19}$ Thethicker outerwalls of the presumed cores, or an exceptionally thick corridor wall (possibly a built-in staircase), older vaulting types, ${ }^{20}$ smaller window openings, and presence or absence of a basement, all might indicate a core within more complex

19 Exceptionally, for defensive reasons the corridor can be shorter or conical. This can be observed in the presumed core of the Lobor mansion, and also in a photograph of the nearby, demolished granary. According to legend, it was the first manor built on the same Keglević estate (Szabo, 19131914, 127-128). Such a variant appears to be identical with the partly reconstructed (?) southern towers of Strmol castle near Cerklje.

20 Occasionally, usually due to earthquakes, vaulting of a newer type was erected (Puhmajer, 2010, 34-35). 
structures. ${ }^{21}$ While newer structures make it difficult to define the original face of the building, they must have usually had at least two levels (occasionally a basement and, as a rule, a brick or stone ground-floor, while the rest could be in wood). The cores are usually situated at one end of the more complex structures. ${ }^{22}$

Putting several simple but massive cubic structures together on some sites could have been done for various reasons, but their respective positions indicates that one possibility to create an efficient form of common defence, albeit only with the help of palisades. ${ }^{23}$ The name fortalitium probably refers to smaller single-room structures featuring some defensive elements, like brattices and loopholes, erected as defence towers on the manor's estate. ${ }^{24}$ All the presumed single-room structures mentioned in this paper were usually built on flat grounds, at the time woody or marshy, or on slight elevations, and, as a rule, close to rivers.

Although the amount of research conducted on this topic is relatively small, the existence of single-room spatial organization appears in a remarkably large sample, indicating the possibility that it might be one of the common building schemes for dwellings in Continental Croatia, i.e. that this is a hitherto unknown layout pattern that might add to the rather poorly known category between a feudal burg and the modest dwellings of the lowest social group in the countryside. In other words, this type of structure would represent the simplest form of feudal architecture which, compared to the typology in more developed territories like Bohemia (Vučetić, 2006, 416-418), is truly rudimentary. This is not surprising, given the civilizational and cultural potential of a relatively poor and backward country on the edge of western civilization, further pushed back by centuries of Ottoman threat, and with an economy that was mainly based on agriculture. The elemental spatial organization of such structures confirms that this style originated in the mists of the Middle Ages. It is hard to imagine simpler dwellings being used by the middle class, consisting of gentry and clergy, and offering

21 Older sections as a rule do not feature a basement, probably due to the vicinity of water and the fact that the soil was marshy before meliorations, but the opposite might also be the case.

22 The presumed core at Miljana mansion can be postulated at the furthermost position, although previous research inconclusively identified the west, larger part of the north wing, as the oldest (Novak, Mirković, 1992, 14-20).

23 Although the scope of this paper does not include an elaboration of this issue, based on the characteristic spatial distribution of their extreme parts, some of the Renaissance castella and Baroque mansions may have developed out of refuges for local people, i.e., serfs and their livestock (for example Bežanec mansion - nomen est omen - Bežanec = place of refuge; in the vicinity of Pregrada). It may have looked like the presumed refugium within which the self-standing early baroque mansion of Freudenau in Črnci near Apače was erected. They may have developed even during the last quarter of the $15^{\text {th }}$ century by including several appropriately situated single-room cores. For example, the Erdödy castellum of Moslavina was de facto given over to the Ottomans after the area became deserted.

24 As depicted in a woodcut from Alphonsus de Spina’s Fortalitium Fidei, printed in Basel 1475. 
a minimum of safety and security, comfort and dignity, and still differing - despite their very modest conditions - from the homes of the ordinary plebs. Even the high nobility must have had various stone or brick buildings for temporary use scattered over their numerous holdings, to store produce or for trade purposes, as documented in the Vinica trgovišče (market place), ${ }^{25}$ as well as for leisure and hunting.

It is only logical that the process of so-called curialisation (Vučetić, 2006, 421422; Horvat-Levaj, 2015, 441), i.e., turning larger estates in northern Croatia during $15^{\text {th }}, 16^{\text {th }}$ and the $17^{\text {th }}$ centuries into small possessions, also of the lower gentry, took place according to the existing infrastructure. Therefore, taking into account these circumstances it is less likely that the nobility, living in relatively modest castles, would erect complex residential buildings on the plains, let alone ones adorned with porticos. ${ }^{26}$ Since the continuity of life at a certain place, including the refitting of older structures, is habitual, we can conclude that the name curia (meaning also 'land possession') might also relate to such simple spatial cores, at least since the $16^{\text {th }}$ century, on the sites where complex Renaissance and Baroque structures were erected at a later time.

\section{References}

\section{Sources}

Institute of Art History, plans collection, Zagreb.

Ministry of Culture, Republic of Croatia, Office for the Protection of Cultural Heritage. Department of Documentation and Photo Collection, Zagreb.

\section{Literature}

Gulin, A., Povijest obitelji Rattkay, Zagreb 1995.

Horvat-Levaj, K., Barokna arhitektura, Zagreb 2015.

Horvat-Levaj, K., Reberski, I. (ed.), Ludbreg - ludbreška Podravina, Zagreb 1997.

Križić Roban, S., Podrumski prostori kanoničkih kurija Kaptol 20 i 24 u Zagrebu, Peristil 40, 1997, pp. 107-116.

25 In the course of conservation research of the former Drašković curia in Vinica, which was sold to Varaždin Jesuits by the mid- $18^{\text {th }}$ century, plastered fronts with rounded corners were found at one end. This roughly square section is considered to be the oldest part of the complex structure (Puhmajer, 2012, 95-98). Taking into account the attempt to organize a three-part plan, consistently achieved in the Zakmardi seminary in Varaždin, indicates the possibility that the curia was enlarged only after being sold (noted by the author).

26 An example of elements and course of emergence is the mansion of Kerestinec, mentioned as such only in the $17^{\text {th }}$ century after the victory over the Ottomans at Sisak, which can be connected to the certainly later incorporation of the corner cores of the castellum into obviously oldest, western residential wing. 
Laszowski, E., Sutinsko i Poznanovac, Zagreb 1943.

Lisac, A.-Lj., Mlinarstvo Zagreba od najstarijih vremena do početka XX. stoljeća, in: Zbornik Odsjeka za povijesne znanosti Zavoda za povijesne i društvene znanosti HAZU 8, Zagreb 1977, pp. 217-290.

Marković, V., Barokni dvorci Hrvatskog zagorja, Zagreb 1975.

Novak, S., Mirković, M., Dvorac Miljana - istraživanja i konzervatorski radovi, Zagreb 1992.

Puhmajer, P., Prilog istraživanju starog magistrata u Koprivnici, in: Podravski zbornik, 2010, pp. 22-43.

Puhmajer, P., Isusovačka kurija u Vinici - građevinske faze i pitanje prezentacije, Godišnjak zaštite spomenika kulture Hrvatske 36, 2012, pp. 91-106.

Reberski, I. (ed.), Krapinsko-zagorska županija - sakralna arhitektura s inventarom feudalna arhitektura - spomen-obilježja, Zagreb 2008.

Regan, K., Srednjovjekovne obrambene građevine porječja Krapine (II.), Kaj 1-2, 2013, pp. 77-107.

Szabo, Gj., Spomenici kotara Krapina i Zlatar, Vjesnik Hrvatskoga arheološkog društva 13, Zagreb 1913-1914, pp. 103-204.

Szabo, Gj., Sredovječni gradovi u Hrvatskoj i Slavoniji, Zagreb 1920.

Vučetić, R., Prilog razvoju i tipologiji kurija u kontinentalnoj Hrvatskoj, in: Dvorci i ljetnikovci - kulturno naslijeđe kao pokretač gospodarskog razvoja, Varaždin 2006, pp. 415-423.

Vučetić, R., Haničar Buljan, I., Nuštar: Dvorac Khuen-Belassy, in: Konzervatorske studije i elaborati Instituta za povijest umjetnosti 2, Zagreb 2012. 


\section{Duško Čikara}

\section{O hipotezi o tlorisnem razvoju kurije Poklek v Zagorskih Selih glede na obrise nepoznanega tipa stavbene arhitekture v kontinentalni Hrvaški}

Ključne besede: enoprostorska zasnova, graščina, utrdba, kontinentalna Hrvaška, srednji vek, zatočišče, renesansa

Na podlagi raziskovanja fasad kurije Poklek podajamo predpostavko o njenem tlorisnem razvoju, pri čemer jedro skozi tri nadstropja sestoji iz prostora štirikotnega tlorisa in ozkega hodnika s stopniščem, zgrajenim znotraj stenske mase. Enak razpored lahko razločimo tudi na tlorisih več baročnih stavb na podeželju ali na urbanih območjih severozahodne Hrvaške. Ob kasnejših neposrednih vpogledih in raziskovanjih posameznih bolj zloženih struktur so bili v dovolj veliki meri potrjeni elementi, ki navajajo na do zdaj nepoznan vzorec organizacije prostora. Predpostavko potrjujejo tudi zgodovinski prikazi stavbe značilnega tlorisa in neodvisni zaključki drugih raziskovalcev. Takšen metodološki pristop se je pokazal kot najustreznejši, saj je v obstoječih okoliščinah povsem jasno, da obravnavane hipoteze v doglednem času ni mogoče potrditi s ciljno in sistematično usmerjenimi raziskovanji na dovolj velikem vzorcu. Zaključke, predstavljene $\mathrm{v}$ tem prispevku, moramo nujno razumeti kot iniciativno zbirko smernic za bodoča, predvsem konzervatorsko-restavratorska in arheološka raziskovanja, $\mathrm{z}$ namenom razširitve in sistematizacije znanstvenega spoznanja o tipologiji in genezi stavbene arhitekture, morda tudi na širšem zemljepisnem področju. Prav na takšna prostorska jedra se od druge polovice 16. stoletja nanaša ime curia. Lastniki so bili pripadniki nižjega plemstva, cerkveni dostojanstveniki, a tudi veliki fevdalci. Gre za najenostavnejšo kategorijo fevdalne arhitekture v kontinentalni Hrvaški na začetku novega veka, pri čemer da elementarnost prostorske organizacije slutiti zgodnejši nastanek. 


\section{Duško Čikara}

\section{From a Hypothesis on the Development of the Layout of Poklek Manor in Zagorska Sela, towards a hitherto Unknown Type of Residential Architecture in Continental Croatia}

Keywords: single-room layout, manor house, fortalitium, Continental Croatia, Middle Ages, refuge, Renaissance

The hypothesis about the development of Poklek Manor House's ground-plan presented in this paper is based on research into its façade, while the three-storey core consists of a square room and a narrow corridor with a staircase built inside the wall. The identical layout can be discerned in the ground-plans of numerous baroque buildings in the countryside or in urban areas of north-western Croatia. During a recent inspection in the field, as well as through research into some of the more complex structures, enough elements have been identified that point to a previously unknown form of spatial organization. This assumption is further reinforced by the historical illustrations of the buildings with typical ground plans, as well as by the independent conclusions of other researchers. Such a methodological approach proved to be the only possible one, since at present it is quite certain that the proposed hypothesis cannot be validated by focused and systematic research on an adequately large sample. The conclusions set out in this paper should thus be taken as an initial set of guidelines for future research, primarily conservation-restoration and archaeological studies, that aim to expand and systematize the scientific assessment of the typology and genesis of residential architecture within what may be significantly wider geographic area. It is concluded that the term curia refers to exactly those spatial cores from the second half of the $16^{\text {th }}$ century. The owners were members of the small nobility and clergy, but also aristocrats, and these curioe represent the simplest category of feudal architecture in continental Croatia at the beginning of the early modern period, while the elemental nature of the spatial organization points to their earlier origin. 